\title{
Observations on Asarum europaeum and its Mycorhiza.
}

\author{
BY \\ E. J. SCHWARTZ, M.A., B.SC., F.L.S. \\ King's College, London.
}

With Plate LXXII.

SARUM europacum, the Asarabacca, is said to form our sole native
representative of the Natural Order Aristolochiaceae; it is, however, questionable as to whether its claims to be indigenous are justifiable. The plant was formerly cultivated for medicinal purposes, a volatile oil, asarol, being extracted from it, and it is probable that the few plants found wild in this country are either 'escapes', or the descendants of 'escapes', from plants so cultivated. The plant, which in its wild state grows in woods and damp, shady places, consists of a branched rhizome which creeps along or near to the surface of the ground, each branch bearing annually two kidneyshaped green leaves with long petioles. These leaves are protected in the bud by a few scale leaves also borne by the rhizome. From the under surface of the rhizome spring a number of adventitious roots, which with their branch roots form the root-system of the plant. The roots penetrate the soil to a depth of from six to eight inches. The flowers resemble those of other members of the Aristolochiaceae in having a three-lobed calyx and twelve stamens, the latter being united to the style to form a gynostemium, thus showing some similarity to a monocotyledon, the similarity being heightened by the existence in the roots of an endotrophic mycorhiza, of a character somewhat resembling that described by Groom (2) as being found in the roots of Thismia Aseroë. The plant, however, is an undoubted dicotyledon, as is evident from the anatomy of its rhizome, and from the possession of two cotyledons by the seedling plant. The affinities of the order are, however, very obscure ; it has been placed with the Santalaceae, Loranthaceae, and Rafflesiaceae to form the class Hysterophyta.

The material used in this investigation was obtained from a small group of plants growing in the garden of my home at Sevenoaks. These plants were uprooted in the early autumn of I III, and portions of the roots

[Annals of Botany, Vol. XXVI. No. CIII. July, 1912.] 
and stems were fixed in Bouin's picro-formol solution. The plants were growing in dense shade, being overshadowed by taller herbaceous plants in the immediate vicinity. The soil was a loam in which clay predominated. In spite of the dry summer it had remained somewhat damp; it was not particularly rich in humus.

Microtome sections of the rhizome and root were cut, and were stained, some with Erlich's haematoxylin and orange G, others with Benda's ironhaematoxylin and orange $G$, and a few with anilin safranin.

Structure of the Rhizome. A transverse section of the rhizome showed the usual dicotyledonous structure. The ring of vascular bundles was of typical appearance, and both fascicular and interfascicular cambium were well differentiated; the hard bast was lacking. The cortical and pith cells were many of them filled with starch grains, although a few of the cells contained oil, presumably the 'asarol'.

No fungus was to be seen in any of the cells, nor were calcium oxalate crystals present either in the cells of the rhizome or of the leaf.

STRUCTURE OF THE ROOT AND ITS MYCORHIZA. In transverse section the root showed either a diarch or triarch stele; one such section with a diarch stele is shown in P1. LXXII, Fig. I. The endodermis had thickened walls, and showed the usual 'radial dot' on the side walls of its cells. The cortical cells of the root contained a lot of reserve starch, which, however, was lacking from the first two or three outer layers, and also from the innermost layers which formed the home of the 'mycorhizal' fungus. In roots free from the fungus, however, all the cells of the cortex contained starch grains except the few outer layers.

Although the cortex of roots containing the mycorhizal fungus may be said to consist of three differentiated portions outside the endodermis-viz. (I) the outer cell layers, two or three in number, free from starch; (2) the median three or four layers of starch-containing cells ; and (3) the innermost two or three layers with the mycorhiza and containing but little starchthese portions are, however, not sufficiently well differentiated and separated to admit of division into exocortex, mediocortex, and endocortex.

In Thismia Aseroë these divisions are well differentiated, and Groom observed in the exocortex a number of sacs containing crystals of calcium oxalate in the form of raphides. Neither these nor any other form of calcium oxalate is to be seen in Asarum. Outside the endodermis the first two or three layers of cells are occupied by the mycorhizal fungus, the cells of the layer abutting on the endodermis containing irregular-shaped masses of fungoid matter as shown in Figs. I, 2, and 3. These masses are highly refractive and are composed of dead portions of fungus, only slender portions of hyphae being as a rule distinguishable in them. The cells are mostly devoid of starch, and are of normal shape and appearance; their nuclei, when visible, show no signs either of hypertrophy or degeneration. 
The appearance presented suggests that the fungus, on entering this layer of cells, has encountered some substance which has caused its death and disorganization, and probably partial digestion by the plant, the irregularly shaped mass left in the cells being composed of portions of fungus, which the plant is incapable of absorbing. Cells of this nature are to be seen in Figs. 2 and 3. Starch grains, when present in these or other cells of the plant, stain blue with iodine solution, and not red, as was the case in Thismia.

The cells of the two or three layers external to that described above are for the most part filled with the coiled hyphae of the fungus, as is shown in Figs. 2 and 3. The fungal hyphae mostly run in a longitudinal direction, as illustrated in Fig. 2, and coil round and round the cell, which finally becomes filled with fungus; the hyphae may infect the neighbouring cell by penetration of the cell-wall (see Fig. 6). Intercellular hyphae also occasionally occur; these run a straight course between the cells and send branches into them which give rise to the coils mentioned above.

The hyphae are very irregular in shape. Sometimes they are swollen out into bladder-like forms, as is shown in Fig. 4; at other times they resemble ordinary fungal hyphae. The bladder-like swellings occasionally found on them bear no relation to the cell nucleus, which when visible in mycorhizal cells is of normal size and appearance; on the other hand, the nuclei of cells in portions of roots which are free from the mycorhizal fungus have sometimes been observed to be considerably enlarged and of abnormal shape.

The fungal hyphae, which are densely filled with granular protoplasm, are non-septate and contain numerous small nuclei, which stain well with Benda's iron-haematoxylin.

The hyphae, unlike those of the fungus in Thismia, do not make straight for the cell nucleus, but, as stated above, form coils in the cells. The fungus is confined entirely to these few cortical layers in the vicinity of the stele, and shows no inclination to spread into the outer region of the cortex with its cells rich in reserve starch. Portions of fungal hyphae are shown in Figs. 4, 5, and 6.

On some hyphae may be seen intercalary or terminal swellings of a spherical or a pear shape. These swellings, which are thick-walled, contain dense granular protoplasm and are multinucleate. They doubtless, if belonging, as I believe they do, to the mycorhizal fungus, represent its resting or reproductive stage. They are not very commonly met with, and it is just possible that they belong to a parasitical fungus which has also obtained an entrance into the root. When met with, however, they are invariably found in the inner cortical layers with the mycorhiza, although the hyphae bearing them are somewhat different in appearance, owing to their staining at times rather more deeply than those of the undoubted 
mycorhiza. These swellings are illustrated in Figs. 7 and 8. In the former figure the swelling is giving rise to a tube which is penetrating a neighbouring mycorhizal cell containing undigested fungal matter.

For the purpose of comparison, the roots of plants of Asarum europxeum obtained from the Chelsea Physic Gardens and from the garden of Mr. E. M. Holmes, at Sevenoaks, were examined. But in both cases these were free from mycorhiza, as were also the roots of Aristolochia Sipho obtained from the same sources. It is, however, by no means unusual for a mycorhizal fungus to be absent at times from a root, the general rule being that when the plant is growing in a soil rich in humus the fungus will be present, and that when the soil is poor in humus it will be absent. It may be added that the roots of plants possessing the mycorhiza were found to possess comparatively few root-hairs, whereas in those which lacked the mycorhiza the root-hairs were more abundant.

Endotrophic and ectotrophic mycorhizas have long been known; the former are commonly to be found in the roots of the Orchidaceae, Ericaceae, and Epacridaceae, although the hyphae are never so deeply seated as in Asarum europaenm. The ectotrophic forms are to be found in the Cupuliferae and many of the Gymnosperms, not to mention numerous other orders in plants of which they have been observed.

The mycorhiza of Neottia Nidus-avis, which bears points of similarity to that of Asarum, has been investigated by Magnus, in I900 (3), who states that the fungus enters the root or rhizome, where it branches and fills up a series of concentric layers of cells. In some cells it kills the host protoplasm, while in others it is itself killed and partly digested by the plant, the indigestible residue aggregating into a ball in the centre of the cell and being covered by a membrane.

In I904 Ternetz (6) isolated a fungus, which was presumably its mycorhiza, from the roots of some of the Ericaceae and stated that it was an active agent of nitrogen-fixation from the atmosphere.

In I 909 Osborn (8) described a fossil mycorhiza found in the lateral roots of Amyelon radicans. According to this authority, the hyphae are non-septate, and they are found in the inner cortical layers of the root, and are apparently very similar to those found in Asarum. He states that some of the cortical cells are filled with coils of fungal hyphae, whereas others, which he designates 'digestive cells', contain irregular masses of fungoid matter. The fungus, like that of Asarum, is limited to the inner cortical layers of branch roots, and is absent from the tissue of the main roots. On some of the hyphae thickened terminal dilatations were found, evidently representing a resting stage of the fungus. These dilatations correspond with the thick-walled swellings observed by me on some of the hyphae in Asarum, and lend support to the view that these swellings belong to the mycorhizal and not to some other parasitic fungus. 
Weiss (5) has also described a mycorhiza from the Lower Coal Measures; it, however, does not bear so many points of resemblance to that of Asarum as does the one on Amyelon radicans.

Significance of THE Mycorhiza. It is difficult, if not impossible, to assign the exact rôle played by a mycorhiza in the nutrition of the plant. It may be, as stated by Ternetz (6), that some mycorhizas have the power of fixing atmospheric nitrogen. Starting from the fact that plants possessing mycorhiza are to be commonly met with in soils rich in humus, Stahl (4) suggests that the fungus aids the plant in the absorption of the ash constituents from the soil. He thinks that the numerous Fungi to be found in a soil rich in humus are severe competitors with any Phanerogams for the available plant food in the soil, and is of opinion that the Phanerogam probably benefits in some way by association with a fungus which might yield up the ash constituents to it. This might conceivably apply to the case of plants possessing an ectotrophic mycorhiza, but certainly is no explanation of such a deeply seated mycorhiza as is found in the roots of Asarum. Moreover, the soil in which the Asarum europaeum was growing was not very rich in humus, nor was it crowded with Fungi.

Stahl also suggests that the fungus may prepare and transform the raw nutritive salts (as absorbed from the soil) into products of assimilation ready for the use of the plant, as for example asparagin. He notes the absence of any form of calcium oxalate, a substance which is usually associated with the assimilation of nutritive salts. As I have stated, calcium oxalate crystals are not found in Asarum. This hypothesis seems to fit in with the facts so far as they are known.

According to Gallaud (7) the Fungi of the endotrophic mycorhiza are 'saprophytes internes', which by means of highly developed haustoria borrow some non-living nutritive material from the cells in which they live. The plant cells finally kill the haustoria, digest, and partially absorb them. The cells, he thinks, defend themselves from the attack of the fungus by their digestive power, and consequently the fungus is but little harmful. Against this view, in the case of Asarum, is the fact of the fungus being confined to the innermost cortical layers and not straying from them. One would expect a parasitic fungus to attack the whole of the cortex and the soft bast of the stele. Gallaud doubts whether any true mycorhizal fungus has been grown isolated from the root of its host plant.

Relationship between the Plant and the Fungus. The question whether the fungus found in the roots of Asarum be a parasite, or whether the relationship existing between the plant and the fungus be a symbiotic one, is of considerable interest.

From a purely morphological point of view, the signs of parasitism may include destruction or hypertrophy of tissue, hypertrophy of cells or nuclei, degeneration of nuclei, unhealthy appearance and poor growth of 
the plant, at times giving rise to its death, and a poor store of reserve food such as starch.

On the other hand, in the case of symbiosis, plants with a symbiotic partner ought to, and do, flourish better than those in similar situations without a symbiont. This is the case in the Leguminosae, in which plants bearing plenty of root nodules, containing the nitrogen-fixing Bacteria, thrive better than those with fewer or no nodules on their roots. Again, the host plant may provide a special home or region for the use of its symbiont; this, however, may likewise be the case in parasitism, as for example oak-galls. We may compare also the root nodules of the Leguminosae with those of the Juncaceae, the former being a case of symbiosis and the latter one of parasitism. With regard to Asanum, there is neither hypertrophy nor destruction of tissue, and the cell nuclei when visible in mycorhizal cells are in most cases of normal size and appearance. On the other hand, a special region of the root, viz. the innermost cortical layers abutting on to the stele, is set apart by the plant for the habitation of the fungus, which for its part makes no attempt to stray from this region. In the cell layer outside the endodermis, the cells were seen to be filled with dead fungoid matter, suggesting that either the fungus was providing food for the plant, and the cells contained the undigested residue left after the absorption of the digested portion into the stele, or that the fungus was a parasitic one which had been killed by this innermost cell layer to prevent its entrance into the stele. The position of the fungoid layers close to the conducting stele, the similarity of the fungus with its coiled hyphae in some cells and irregular dead masses in others to the mycorhizal Fungi of Thismia Aseroë, Neottia Nidus-avis, and other roots, are all facts which favour the former interpretation. The shade-loving nature of the plant, and the presence of humus in the soil, also point to the same conclusion.

It is evident from the deeply seated situation of the fungal home that the fungus obtains all its nutriment from the plant, although some of it may be in a raw state, unaltered by the plant since its entrance into the root from the soil. The carbohydrate is apparently supplied by the reserve starch of the root, which is mostly absent from the mycorhizal cell layers, or the fungus may feed on the sugars supplied by the green leaves to the roots, these sugars being converted into starch in those cells of the root which are free from fungus. As far as the facts observed warrant the expression of an opinion as to the function of deeply seated endotrophic mycorhiza; one is inclined to accept Stahl's hypothesis that the rôle of the fungus is to elaborate the raw salts absorbed from the soil into organic compounds such as asparagin, and in this connexion the lack of calcium oxalate crystals from Asarum roots is suggestive. The diminished numbers of root-hairs on mycorhizal roots is difficult to explain when we have such 
a deeply seated mycorhiza as in Asarum. In cases of ectotrophic mycorhiza root-hairs may be absent altogether.

In conclusion, my thanks are due to my sister, Miss Alice M. Schwartz, for her kind assistance with the drawings.

\section{Summary AND CONCLUSions.}

I. The roots of Asarum europaeum are inhabited by a fungus which is limited to the cortical region abutting on to the steles of young roots.

2. This fungus is very similar to those found in Thismia Aserö and Neottia Nidus-avis.

3. Thick-walled swellings are to be found on some of the hyphae, representing a resting stage of the fungus. These correspond with those on the fossil fungus on roots of Amyelon radicans.

4. The fungus forms an endotrophic mycorhiza in most respects similar to those found in other roots.

\section{BIBLIOGRAPHY.}

1. Groom, Percy ('94): Contributions to the Knowledge of Monocotyledonous Saprophytes, Journal Linn. Soc., read Dec. 20, 1894.

2. ('95): On Thismia Aseroë and its Mycorhiza. Annals of Botany, vol. ix, No. xxxiv, June, 1895, p. 327 .

3. Magnus, Werner ('00): Studien an der endotrophen Mykorrhiza von Neottia Nidus-avis. Jahrb. f. wiss. Bot., xxxv, I900, p. 205.

4. Stahl, E. ('00) : Der Sinn der Mykorrhizenbildung. Jahrb. f. wiss. Bot., I900, p. 539.

5. Weiss ('04): A Mycorhiza from the Lower Coal-measures. Annals of Botany, vol. xviii, April, 1904 .

6. Ternetz, Charlotte ('04): Assimilation des atmosphärischen Stickstoffs durch einen torfbewohnenden Pilz. Ber. d. Bot. Ges., xxii, 1904, p. 267 ; Jahrb. f. wiss. Bot., xliv, 1907, p. 353 .

7. Gallaud ('05): Études sur les mycorhizes endotrophes. Rev. Gén. Bot., xvii, 1905 .

8. OsBorn ('09): Lateral Roots of Amyelon radicans and their Mycorhiza. Annals of Botany, vol. xxiii, October, ryog. 


\section{EXPLANATION OF PLATE LXXII.}

Illustrating Mr. Schwartz's paper on Asarum europaeum and its Mycorhiza.

Fig. I. Transverse section of root, showing position of fungal layers. $\times 325$.

Fig. 2. Longitudinal section of root. $\times 325$.

Fig. 3. Longitudinal section through fungoid lavers. $\times 730$.

Fig. 4. Bladder-like swelling on hypha. $\times 1,180$.

Fig. 5. Hypha with nuclei. $\times 1,180$.

Fig. 6. Hypha piercing cell-wall. $\times 73^{\circ}$.

Fig. 7. Resting body of fungus, germinating. $\times 730$.

Fig. 8. Terminal hyphal swelling forming resting body. $\times 730$. 
Arrials of Botany,

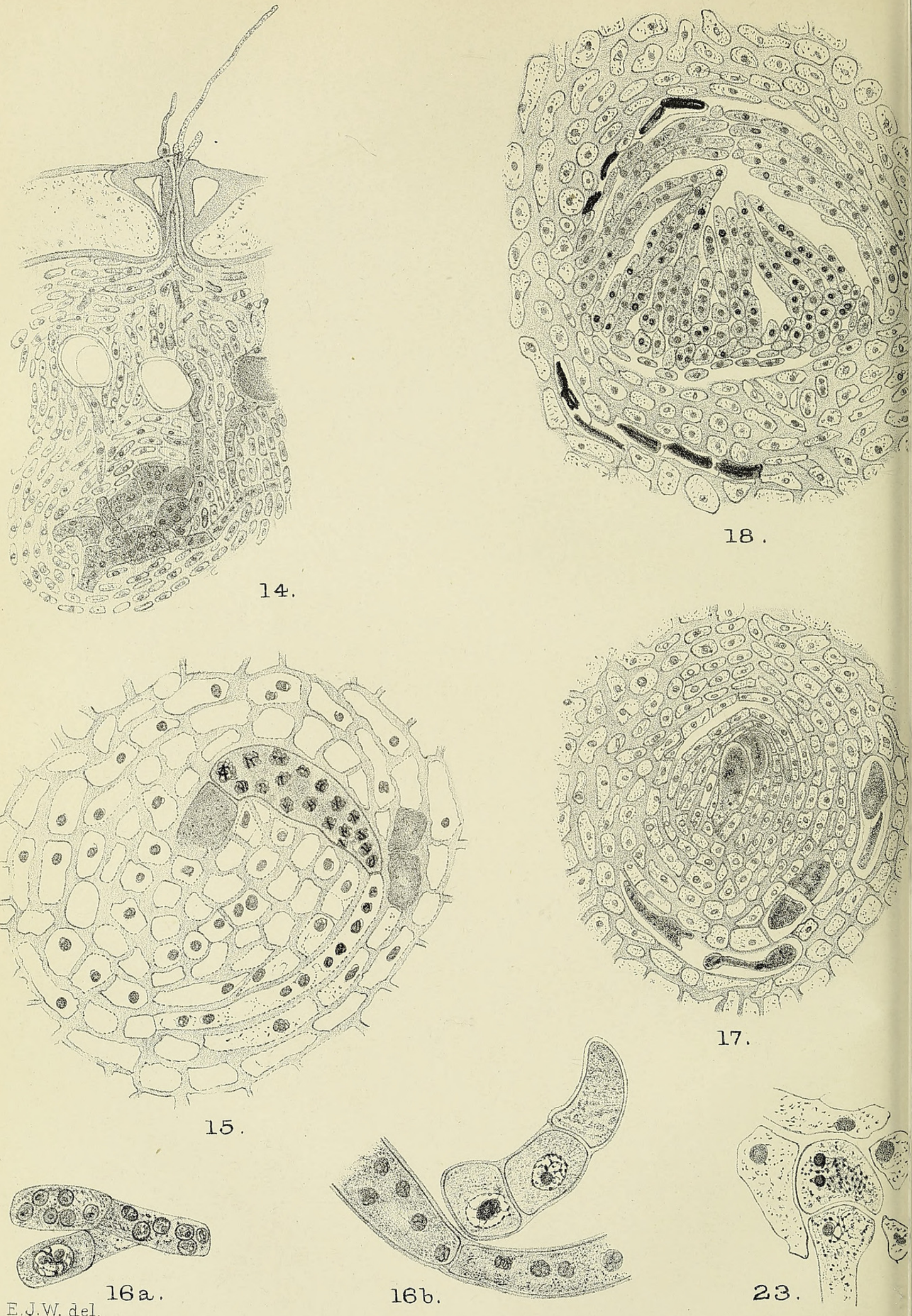

BLACKMAN \& WELSFORD - POLYSTIGMA , 

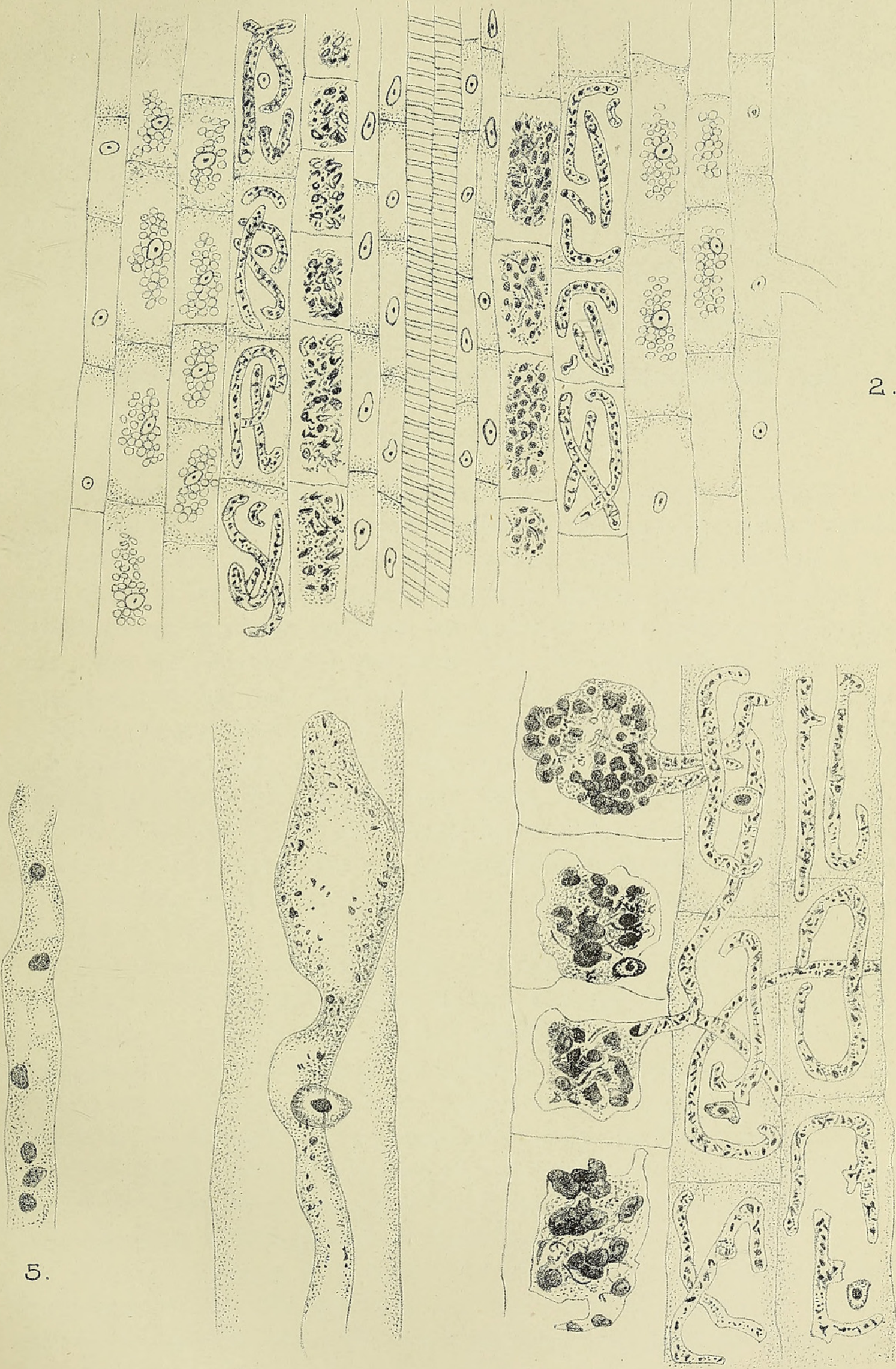

3.

4. 


\section{$2 \mathrm{BHL}$ Biodiversity Heritage Library}

Schwartz, E. J. 1912. "Observations on Asarum europaeum and its mycorhiza." Annals of botany 26, 769-776.

https://doi.org/10.1093/oxfordjournals.aob.a089415.

View This Item Online: https://www.biodiversitylibrary.org/item/236930

DOI: https://doi.org/10.1093/oxfordjournals.aob.a089415

Permalink: https://www.biodiversitylibrary.org/partpdf/319928

\section{Holding Institution}

Smithsonian Libraries

\section{Sponsored by}

Biodiversity Heritage Library

\section{Copyright \& Reuse}

Copyright Status: Not in copyright. The BHL knows of no copyright restrictions on this item.

This document was created from content at the Biodiversity Heritage Library, the world's largest open access digital library for biodiversity literature and archives. Visit BHL at https://www.biodiversitylibrary.org. 